Hugoye: Journal of Syriac Studies, Vol. 9.2, 235-250

(c) 2006 [2009] by Beth Mardutho: The Syriac Institute and Gorgias Press

\title{
TRAVELOGUE
}

\section{ENCOUNTERING THE SURYOYE OF TURKEY}

\author{
JEANNE-NICOLE SAINT-LAURENT
}

\section{BROWN UNIVERSITY}

The early Christians traveled from distant lands to touch sacred places and to gaze upon the faces of holy men and women who shined forth as vessels of divine love. ${ }^{1}$ In the tradition of visiting living saints and seeing the landscape against which they are situated, scholars and students made a similar journey to the loca sancta of the modern Syriac-speaking churches in August 2005. Through the expert organizational skills and enterprising spirit of Dr. George Kiraz, and on account of the support of many self-sacrificing people along the way, ${ }^{2}$ we visited the Christian sites

1 I am borrowing this imagery from Georgia Frank's work on pilgrimage to visit the living saints in late antiquity. See The Memory of the Eyes: Pilgrims to Living Saints in Christian Late Antiquity (Berkeley: University of California Press, 2000).

${ }^{2}$ Here, the group would like to thank the following generous people in particular for their help and labors of love to make the trip a reality. Firstly, my advisor Susan Ashbrook Harvey of Brown University and Ms. Christine Athanasiopoulos at the Greek Orthodox Archdiocese in New York for arranging for the group to be received in an audience with His All Holiness the Ecumenical Patriarch Bartholomew on August 7, 2006. We would like to thank also Fr. Edip Aydin of Princeton Theological Seminary for arranging a meeting for our group with the Syriac Orthodox Bishop of Istanbul His Eminence Mor Filuksinos Yusuf Çetin. We would like to thank İshak and Sara Tanoğlu for arranging our visit to Harput and Elazığ. We would also like to thank Elif and Savas 
of Istanbul, Tur Abdin, and Harput, August 3-18, 2005. The trip was organized by Dorushe, the graduate student organization affiliated with Beth Mardutho: The Syriac Institute. Each day uncovered new pearls for us, as we encountered the distant voices of the Syriac past as well as the living faces that comprise the modern churches of the Syrian Christians in Turkey.

Our group itself was a felicitous blend of students, scholars, and enthusiasts of Syriac. George Kiraz of Beth Mardutho came with his wife Christine, who co-directs Gorgias Press, and they brought their two children Tabitha (4) and Sebastian Kenoro (2). Having these youngsters, who are fluent in Kthobonoyo Syriac, brought joy to the group and impressed the local clergy and people of Tur Abdin. George's sister, Alaria Saar, and her friend HoangAnh Do, came from California, and with their pharmaceutical knowledge they helped to keep our bodies calm from the spice of Turkish food. Rev. Dr. Paul S. Russell, a Syriac scholar, joined us from St. Joseph of Arimathea Anglican Theological College in Berkeley, CA. Prof. Alison Salvesen from Oxford University accompanied us as our group Syriac scholar. Hidemi Takahashi, a Bar Hebraeus scholar of boundless curiosity and encyclopedic knowledge of Syriac Christianity, joined us from Chuo University, Tokyo (he has since transferred to the University of Tokyo). Our graduate student constituency included Carl Griffin from Brigham Young University, Jonathan Loopstra from the Catholic University of America, Miriam Goldstein from Hebrew University of Jerusalem, Mark DelCogliano from Emory University, Rev. Gareth Hughes from Cardiff University in Wales, and myself from Brown University. In all, we hailed from four countries, six universities. Thus fifteen distinct personalities came together to create a wealth of knowledge and energy for the group.

We spent the first few days in Istanbul as we joined together from various countries. We visited the magnificent Hagia Sophia/Ayasofya, once the great church of Byzantine Christendom. We also saw the Chora Church and enjoyed the beauty that adorns Turkey's historical center. The true highlights, however, were meeting the groups of Christians in Istanbul: both

Ulvi Kayaalp for their help in arranging our flights to Diyarbakir. Many thanks to İsa Doğdu for arranging our visit to Mor Gabriel, our busses around Tur Abdin, and our hotel in Mardin. We would also like to thank the Aziz family for arranging our stay at the Bektaş Hotel in Istanbul. 
the Greek Orthodox and the Syriac Orthodox. The Armenian Apostolic Church and the Roman Catholic Church also have important communities in Istanbul, and all the Christian groups together have solid and sisterly relationships. We attended the evening prayer of the Syriac Orthodox community in a church outside of Istanbul. The people greeted us with warm hospitality, and His Eminence Filuksinos Yusuf Çetin, Syriac Orthodox Metropolitan for Istanbul and Ankara, invited us to a reception. He shared with us the current situation of their church in Istanbul, and he related his efforts to strengthen the community of the Suryoye in the city through reaching out especially to the young people of his flock. He spoke of the struggles of being a minority religion in Turkey, and he emphasized the importance of keeping a close relationship with the monastic communities and dioceses of Tur Abdin and Harput. The bishop gave us generous souvenirs from our visit. The nuns living there at his residence prepared a delicious meal for us, and we met some of the pillars of the Istanbul Suryoyo community.

On Sunday, August 7, we traveled to the Phanar district of Istanbul to attend the liturgy celebrated by His All Holiness the Ecumenical Patriarch Bartholomew. There, we celebrated with the Orthodox Church the morning prayers and divine liturgy, in the presence of the relics of John Chrysostom and Gregory of Nazianzus. Our group had the honor of being received by the Patriarch, who bestowed gifts on us. He shared his vision for the Church, his efforts to attend to his local and global flock, and his personal dedication to causes like the protection of the environment. A man of grace and humility, he blessed the baby Sebastian Kenoro Kiraz. He told us how much his Church needs the prayers and love of the global Christian community.

Monday, August 8, we flew to Diyarbakir in Southeastern Turkey, where our bus drivers Elias (from Midin) and Faulos (from Beth Qustan) greeted us. It was a delight to hear the beauty of their spoken Syriac, and in the vans we were graced to listen to the modern music of the Suryoyo community! We drove into Diyarbakir, ancient Amida, and we visited the Syriac Orthodox church of the Yoldath Aloho (Meryemana). The church, the seat of the patriarchate for brief periods in the 1860's, is set off by walls, and as one enters one sees a small garden that the small community tends. The women were working outside in the shade on their 
quilting and drying fruits and vegetables. The walls of the church contained many beautiful inlaid Syriac inscriptions. The church itself contained the relics of Dionysius Bar Salibi and the tomb of Jacob of Sarugh. The priest who received us in the church, Fr. Yusuf Akbulut, had the experience, in 2000-2001, of spending some months in cells-which were not of the monastic kind-for talking in public on the genocide of the Christians in the early $20^{\text {th }}$ century. We also visited the church of Mar Petyon, which is Chaldean Catholic. There was once an Armenian church in Diyarbakir (now occupied by a Kurdish family), but we were unable to get inside. What was the main church of the city is now a mosque, reminiscent in its style, though smaller, of another edifice with a similar history, the Umayyad Mosque in Damascus. After leaving the city with its formidable basalt wall, we stopped along the Tigris River at an old stone bridge, built in 1065. We coasted alongside the River for another hour before reaching Mardin, our home for the next four nights.

Our second day in the area around Tur Abdin took us to the once mighty fortress-town of Dara. There is an interesting depiction there of a risen Christ on the outside of a cave. We visited the necropolis and underground cistern, and the local children there gave us flowers. We climbed below to a church now underground that had been a temple to the sun gods worshipped by ancient Mesopotamians. Outside we saw a structure with "channels" that had once been covered by arches. It seems to have been a storage area for grain-logical, as pointed out by Dr. Salvesen, given the constant back and forth of armies in the region that would have used such grain stores.

We drove further to Nisibis, modern Nusaybin, to visit the city that was once a stronghold for Syriac literature and learning, the place St. Ephrem and St. Jacob called home. We visited the impressive church of Mor Yacqub with its double altars. On his journeys as bishop, Mor Yacqub had seen the bigger churches of cities like Nicaea, and he decided that Nisibis deserved one, too. We climbed down to the crypt of the city's great fourth-century church that lies underneath the altar to touch the tomb of Mor Yacqub. We walked around the outside of the church that has been partially excavated, and was completely underground until three years ago. We read inscriptions on its hallowed walls. While in the church with the tomb of Mor Yacqub beneath our feet, Dr. 
Salvesen lectured for the group on Syrian Christianity in the Nisibene area. Dr. Salvesen related the history of the area around Nisibis, drawing on the information from the Syriac Chronicles. The School at Nisibis has not yet been excavated.

We spoke with other pilgrims in Nisibis who had come from Germany. Political danger had driven them from their village of Mor Bobo nearby, and the father had taken his daughters back to the Tur Abdin area so that they could reconnect with their roots. We also met as a large group of Christians from the city of Qamishli in Syria, just across the border from Nisibis. From Nisibis we drove up the valley along the ancient Mygdonius and had lunch by the headwaters of the White Waters (Maye Hewore) where we cooled down with kebobs. This restaurant/picnic area suspended on rafts over the water was a refreshing break from the scorching weather, and we visited with a number of Kurdish Muslim families who had come back for summer visits to the area. We could speak to the children in German or French, and they translated for the parents, who, despite the relatively long period they had been in Europe, were limited in languages other than Kurdish. Kurdish musicians serenaded us on the kemanje and other regional instruments.

We drove on into the heart of Tur Abdin, on the way passing over the watershed between the Tigris and the Euphrates. We arrived at the Monastery of Mor Gabriel, where the Metropolitan Bishop of Tur Abdin, Mor Timotheos Samuel Aktaş, greeted us and offered us tea and watermelon. We met Malfono Isa there, who busily works as a teacher at Mor Gabriel, teaching local boys such as Faulos (who spoke both Kthobonoyo and modern Syriac, as well as Kurdish, Turkish, Arabic and some English!), as well as Suryoyo youth who arrive from Europe to study for a period of time before beginning university back home. Isa gave us a tour of the monastery and the churches, much of it recently refurbished. It was stunning in its monumental beauty. The main church at Mor Gabriel has a beautiful mosaic floor and altar. Behind the altar we climbed up into the cave where ascetics would watch and pray in solitude. He took us to the Beth Qadishe (burial area), and we touched sacred relics. We saw the eating areas and the beautiful fields below where the monastic community grows crops. The women in our group also went to the convent to meet the nuns. Our reception at Mor Gabriel was warm and unforgettable. 
We went to Ramsho prayer service with the people, in a plain but beautiful chapel, and then we continued on to supper with them: simple fare, including yogurt-barley soup. We sat upstairs for tea afterwards and spoke with visitors - the monastery is a popular destination amongst Christians from Syria. Among them were visitors from Melkiyya (the hometown of Mor Severios Malki Murad, current Syriac Orthodox bishop of Jerusalem) and Qamishli.

On August $10^{\text {th }}$, we began the fast before the feast of the Assumption, or 'Transfer' (shunoyo), as it is called in Syriac. We traveled northeast from Mardin, on the Mardin-Midyat road to Qelleth (Syr.) /Qillith (Arab.). Although the historic route from Mardin to Midyat passed through Qelleth, today the village is not off the modern main road. Thus, it took quite a long time to find this village, yet we realized as soon as we arrive that it was worth the effort. Once a populated Christian town, all the Christians have since left. However, we met a man there who has returned to restore the Syriac Orthodox church there, Mor Yuhanon. He had left the village for Sweden sixteen years before. The Swedish Syriac Orthodox community is funding this project. Today only two families remain in the village. Qelleth is rather isolated and must receive supplies intermittently from other towns. There is a small graveyard there, where one sees the grave of the mukbtar who was killed by the Kurds in 1992. Above the altar in the church reads Ilono d'baye - tree of life. Sebastian and Tabitha ran all around the church, as the scholars sorted through a pile of manuscripts and papers in the back of the church. Others explored the remains of houses, doing their best to avoid the bats! There are ruins of three monasteries in the area, Mor Abai, Mor Dimet, and the "Monastery of the Headache," the last visited by those seeking cure from migraine. Additionally, the town has abandoned Syrian Catholic and Protestant churches. Some work had been done to restore the Protestant church.

We also visited the town of Bnebil, where we met a charming eighty-five year old priest, who recounted stories of the struggles, resilience, and valiance of the Christians in recent history. The priest Yacqub bar Isa Shem'un Kfarzoyo (Yakub Günay in Turkish) lives there with his wife. Although they are both in their eighties, they are flourishing with stalwart spirits. Fr. Ya $a^{c}$ qub was ordained a priest in 1954. Some of us remained outside and spoke with the 
priest's wife, a small woman with thick glasses, who spoke of the difficulties of life in the town. Eight Christian families and two Muslim families remain. The church contained among its many treasures that the qashisho showed us, a manuscript from the pen of the scholar-bishop Filuksinos Yuhannon Dolabani. Fr. Yacqub told us how fifty people had left Bnebil after fights with the Muslims in the 1960's, and many had fled to Syria or Istanbul. In 1915, the Kurds had come and killed four of the city's leaders. The church has received aid from Sweden to help restoration efforts. As we left Bnebil, we could see the Monastery of Mor Stephanos in the cliff above the village.

In the evening, we went up to the stunning Dayr al-Zacfaran, the saffron monastery perched on a hill overlooking the plain to the south of Mardin. As we arrived, it was nearing sundown. We quickly prepared to ascend the hill atop the monastery, where four other monasteries for solitaries lie. A young man who was living at the monastery, Ephrem, led us up through the bushy terrain, and after a half hour of steady climbing, steep and difficult in some places, we reached the monastery of Our Lady of the Drop [Yoldath Aloho d-Nutfo/Dayro d-Nutfo]. It is perched on the top of the mountain, carved into the face of the rock, with stunningly beautiful views over the plain below and Dayr al-Za'faran. Only silence dwells there now, and the spirits of the monastics who had prayed there for centuries filled the summer evening with comfort and assurance. We gathered as a group in the chapel and gave thanks- "it was good to be there." On the climb downwards, although it was nearly dark, we followed the way of a shepherd and his sheep, and we reached the monastery by evening.

Some special guests were awaiting us inside Dayr alZacfaran. The great living light of Syriac learning, Malfono Abrohom Nouro, happened to be there visiting from Aleppo, and his presence and refulgent spirit was a grace. He spoke to our group about his life's work and passion: the promotion, pedagogy and scholarship of the Syriac language. His energy was boundless, and we were able to buy signed copies of his books on learning Syriac, including Souloko. We also met Hatune Doğan, a Syriac scholar and teacher originally from the village of Zaz in Tur Abdin, but who now lives in Germany. She has been working with young women coming to Dayr al-Za'faran from abroad to learn Syriac. She spoke of her efforts to promote girls' education in the 
monastery. Metropolitan Filuksinos Saliba Özmen of Mardin, who lives in Dayr al-Za'faran, greeted us warmly and sat and talked with us for a long while. There was a lively exchange between the bishop and the scholars from Britain, who updated him on the state of Syriac Studies at Oxford, where the Bishop had studied. His Eminence gave us much love and thoughtful presents, and Dr. Salvesen gave him his favorite English tea. We also received a tour of the monastery, seeing the places where the patriarchs and bishops of the past were buried in the walls. We visited the living quarters of the bishop. Many pilgrims were simultaneously visiting as we were there. We shared a lovely meal with the people there, and later we drove back to Mardin, high above the plain.

The next morning, we woke up early to set out on the three hour drive to Urfa, or ancient Edessa/Urhoy. The drive between Mardin and Edessa is long and dry, and we planned to do it in one day. We passed by Viranşehir-ancient Tella. As we reached Edessa, we were struck by a town buzzing around with people and traffic. We stopped for a drink of ayran and some bread and pastries in a park before beginning our excursion. We walked to the top of the towering citadel protecting the city, and we investigated its two columns with their famed Syriac inscription. The two large columns are also called "Nimrod's throne," and according to legend Abraham was launched from them when he was a baby. He was caught by a pool, where holy carp now swim. After climbing around the citadel, we walked down to see the carp.

The museum of the city contains outside the lovely mosaics from ancient Edessa known to us from Segal, ${ }^{3}$ but they are outside, unkempt, and dusty. The outside yard of the museum contains Christian funerary inscriptions and tombs, as well as pillars, Roman statues, Hittite engravings of archers, and inscriptions from Tella and other important historical sites. It was painful to see these treasures, in Syriac, Greek and Ottoman Turkish, unlabeled and "maintained" outside in questionable conditions. The inside of the museum contains the sad remnants of the twentieth-century atrocities against the Christians in Edessa: statuettes of saints from modern churches now stripped sit in the museum and gather dust. Some of us wandered around the streets of Urfa—two main streets

${ }^{3}$ J. B. Segal, Edessa 'The Blessed City' (Piscataway: Gorgias Press, 2002, $2^{\text {nd }}$ edition). 
that designate the earlier flow of the Daysan before its rerouting by Justinian, which flank the raised level of the town itself. We visited many churches that have been transformed into mosques, such as the former St. John's church, where the two building structures were clearly once a church and baptistery. We were led to the former Armenian church, now a mosque, by three locals, 20something-year-old Turks who were happy to tolerate our primitive Turkish! We also wandered around in the bazaar, which was built by Suleiman the Magnificent.

We were unsuccessful in locating the rock tombs described by Segal as being in the hills to the west of the citadel, being directed first to the modern town cemetery, a result of the unsuccessful combination of Said's (our bus driver) Turkish and Miriam's Arabic. Edessa's vestiges of its shiny Christian past are difficult to discern now, as mosques stand where once Ephrem's church would have been. Egeria who visited Edessa in the fourth century would probably not recognize the town there, yet we perceived with our hearts through the spirit of the city the beauty that earned Edessa the epithet of "blessed." We stopped through Harran on our way back, braving nearly five kilometers of unpaved road, apparently part of the Turkish efforts at renewing the region along with the new dam. The town walls have been partially restored, as well as one of the gates, and we drove inside the village to see the famous beehive houses. The aggressive behavior of the locals encouraged us to leave Harran quickly, following Abraham's example!

On August 12, we continued our tour of the villages of Tur Abdin. We drove to Azekh, also known as Idil, a town to which the Kirazes could trace their maternal roots. In Azekh/Beth Zabday we met a small group of Suryoye jewelers who had set up their shop for business, having returned to Azekh after living for a time in Germany. We bought some presents for our loved ones back at home. The Suryoye shared with us how they had single-handedly raised up their church from the rubble, and they were working tirelessly to reestablish a strong foothold of their Christian community in Azekh. They took us inside the church. They narrated to us how the people of Azekh "held on" in 1915 for forty days while their village was attacked. Likewise, in 1923 the Christian women of Azekh had fiercely warded off the Turks with stones, and they attributed their success to help from the Virgin 
Mary, for whom the church of Yoldath Aloho is named. Our guides also told us about the German military adviser (WWI) who was with the besieging army, who decided to become a monk following this miraculous victory. He reportedly later became a cardinal!

When the people here speak of their roots, their tone of voice reveals the pride they had in the strength of their forefathers. We were joined in our visit to the church by Suryoye visiting from abroad, such as Gabriel, who left 25 years ago. He now lives in Holland and has children whom he has named Nineveh, Babel and Salin (former name of Qamishli). Many of these visitors stay in town during the day, but sleep in the guest rooms at Mor Gabriel. They spoke of the importance of preserving their culture and heritage.

We traveled onwards to Midin, a town that remains wholly Christian. Our bus driver Elias hails from Midin, and he showed us where he had grown up and played football as a boy. Suzy was our guide in Midin. She had returned to Midin five years previously, after living for twenty years in Germany. She was energetic and young-looking-“I don't feel 40!" Her husband had died prior to her return to Midin, and she told us it was not easy for her to make ends meet. She shared that the locals receive few "tourists" in Midin. We visited also the church of Mor Sobo in the courtyard of a local house in Midin, and it lies half underground. The main Church in Midin is named after Mor Yacqub of Sarugh, which was originally built in 450 AD. It was destroyed during Timur Lane's invasion of the area and rebuilt in 1525 . We were told that there were three other churches in use-Mor Barsaumo, Mor Zokhe, Mor Yuhanon Ma'mdono/John the Baptist. In all, twenty churches adorn the town! Around fifty-five families live in Midin today, and they keep themselves isolated from the non-Christian population around them.

We then visited Beth Sbirino, where a charming boy who spoke excellent German showed us the main church of Mor Dodo. There, we read manuscripts in Karshuni with the local malfono-he enjoyed it as much as we did! There were once twenty-five churches in Beth Sbirino.

On August $13^{\text {th }}$, we traveled to Salah, where there is only a very small, but valiant Christian community now. We visited the Monastery of Mor Yacqub, once the seat of the "patriarchs of Tur 
Abdin." Here, a number of monks and nuns have come to live, after restoring the church and setting it up for visitors splendidly. Aziz Bolan, the only Christian left in the town, received us. We spent a good part of the morning examining the numerous inscriptions around the entrance to the church, and then Aziz gave us a tour of the whole complex, including excavations undertaken near the back. Aziz was quite happy to take us into town to see houses and churches once belonging to Christians. We followed Aziz through the village, trying to avoid the open running sewage in the streets and the barn animals roaming freely, and he took us to the church of Mor Aphrem which is used now as a cowshed.

In Hah, we went to the radiant church of Yoldath Aloho. There are about twenty Christian families there today. According to legend, this church is the oldest church in Christendom, built by the kings from the East on their way home from Bethlehem. (According to more "scientific" accounts, it was originally built in the $7^{\text {th }}$ or $8^{\text {th }}$ century.) It is a restored jewel against a beautiful desert landscape, unique in its octagonal shape, and intricately decorated inside. The eve of the great feast of the Assumption was in the air, and pilgrims whom we had met along the way were preparing for the overnight stay in Hah. We ate lunch there along with Faulos, and we very much enjoyed the cooking of the friendly woman running the kitchen. In Hah, we also went to the ruins of Mor Sobo and wandered around in its buildings and graveyard.

Next, we stopped at Bakusyone, or Beth Qustan (Constantine), the home of both the eponymous abbot and present bishop of the Monastery of Mor Gabriel. The church there is named Mor Eliyo. This was also the hometown of our bus driver Faulos, and we got to meet his little baby boy while passing through. It has been greatly restored, as well.

We drove onwards to the lovely Dayro da-Slibo, where five Christian families have returned from Europe to live in the old monastic complex. The main church is dedicated to the Holy Cross. The smaller building to the right was the church (grave) of Mor Aho. The nun who lives there now, Maryam, is a sprightly and intelligent woman, who spoke to us in Arabic as she climbed up and down the ecclesiastical complex, which has been lovingly restored by the Swedish Suryoye community. The monastery is built "higgledy-piggledy" with staircases all around. Sister Maryam's brother Gabriel was also there. We also met Khālisa, who was 
drying salted tomatoes on the roof of the church! We sat and drank tea and cold water (getting brave-not from bottles!) with Maryam. Despite her sprightliness, it was clear that she had huge responsibilities in taking care of the large complex.

Then we drove back to Midyat, and we stopped outside the town to see the Monastery of Mor Abrohom and Hobil, founded in the fifth century. We then entered Midyat and visited Mor Shimuni. Inside the church, Faulos opened up a grand copy of the Syriac Gospels with colored pictures, and he read with us. We read inscriptions on the baptistery and all over the church, and those of us with less experience with inscriptions were helped by our comrades as well as our driver! It is worth mentioning that Faulos was far beyond a mere driver, serving as translator between the numerous languages mentioned above, as well as correcting our Syriac reading!

We visited the church Mor Barsaumo in Midyat, where the faithful were emerging, each with two loaves of bread, in observance of a funeral of a priest who had been killed in a car accident the day before. There, Malfono Ayhan showed us his classroom, and we saw the bread baking for the next day's mass on a coal stove. We were hungry, and it smelled great! The drive back from Midyat in the evening was beautiful, and we watched the sunset and as we passed through small villages.

On Sunday in Mardin, we visited the church of the Forty Martyrs, where we attended the Divine Liturgy. We were received by the bishop of Mardin/Dayr al-Za'faran, Bishop Saliba. We sat in his beautiful salon with many of the faithful and drank bitter coffee (due to the funeral the day before). Mardin was the seat of the bishop, who is now in residence at Dayr al-Za faran. It was the center of the patriarchate until 1933, when it moved to Homs in Syria. The church there, named for the Forty Martyrs of Sebaste, is 370 years old. The interior is beautifully decorated with icons of saints, including a stunning one of the Martyrs of Sebaste meeting their chilly death. The church was quite full for the Sunday liturgy.

Our beautiful Hotel of the Caravansaray in Mardin, with a stunning view from its top deck, made a wonderful home base for us. We often walked up and down the streets of Mardin, smelling fresh bread and spices. Miriam and I rose at 6 am each morning to run around the city-and to work-off delicious baklava! 
We headed north the next day-a long drive-to Elazlğ, stopping in Diyarbakır for lunch. We passed through a canyon area and drove by a large beautiful lake. In Elazığ, we were met by the friendly Tanoğlu family, who took us to the church of Mor Giwargis. The church of the Syriac Orthodox community in Elazığ is small and simple, to support a community of a few families.

Our group was treated to three excellent lectures by the poolside of our hotel in Elazı $\mathrm{g}$. The first was from George Kiraz, who directed us in improving our spoken Syriac, using John Healey's book Leshono Suryoyo: First Studies in Syriac (Piscataway, NJ: Gorgias Press, 2005). Hidemi Takahashi reviewed with us his scholarship on Bar Hebraeus, referring us to his book Bar Hebraeus: A Bio-Bibliography (Piscataway, NJ: Gorgias Press, 2005). We then heard from Alison Salvesen, who spoke about how Syriac writers of the fourth century, like Ephrem, describe or identify themselves in relation to the area in which they grew up. She mentioned, for example, that Ephrem's fourth hymn on Julian Sabas referred to our land as the land of Abraham, Jacob and the patriarchs. She also spoke about Jacob of Edessa's pride that Syriac was a language close to Hebrew, although he himself was "pro-Greek." For the East-Syrians, in contrast, Hebrew had less prestige, but the biblical references to Aram were very important. She spoke about the evolution of the term "Syrian," and the linguistic and geographical definitions that developed throughout the first millennium CE.

For the feast of the Virgin Mary, we drove up to the city of Harput, and the church of Yoldath Aloho. Harput has long been a center of Syriac and Armenian Christianity. The church in Harput dates from the second century, and has long been a place of pilgrimage to Mary. Although the majority of Harput's citizens left at the beginning of the century, the church has remained, strong and beautiful atop the cliff with a vast plain extending beneath it. The church has a cavernous feel to it, and when one enters, one is greeted by beautiful icons and the smells of candles and incense. The pilgrims came for the feast of Mary on August 15, after fasting six days before. On the day that we were there, we met Christians who had come from as far away as Adiyaman and other places, journeying to honor the Blessed Virgin Mary. The divine liturgy was beautifully offered, in Syriac, Arabic and Turkish, and afterwards we feasted with the others who had journeyed there at a 
café overlooking the modern Elazığ below. The community was remarkably friendly.

Later that day we had the treat of visiting the historic restored house in Harput with an energetic and witty guide, Rabban Melke, who rattled off a spirited tour in Syriac, Arabic, and Turkish. A house there has been restored in order to show the way people used to live in Harput, and there are plans to expand the complex in coming years. They proudly took out the architectural plans to show us. Rabban Melke showed us around the house. A few of us then went to explore the fortress of Harput following the visit.

On our last day, we drove out to Malatya/Melitene, once the center of Syriac Orthodoxy in the days of such men as Patriarch Michael I, Dionysius bar Salibi and Bar Hebraeus. Thanks to Hidemi's and George's endless curiosity, our drive to Melitene took us "off the beaten track" in order to glean more information about the abandoned Armenian churches we passed along the way. We crossed (or ran on foot) over the Euphrates and stepped out of the van to drink in the beauty of the natural surroundings. We spotted the sign of a church/monastery on our map, and then we decided to backtrack a bit in order to discover more about it. Our drivers stopped along the side of the road in order to ask some local farmers where we should go. They instructed us, and then after learning that we were Christians, launched into a theological discussion with us. They wanted to know how it was that Christians believed that Jesus was God. I was impressed at their curiosity, but as we had left our notes on Nicene Christology at the hotel, we continued on our way in search of the church. Up through the thorny bushy path we climbed until we reached the ruins of an Ottoman fort on top of the hill. We never, alas, found the monastery of Tomisa.

We continued on to Malatya, which is the mishmish or apricot capital of Turkey, where we drove through the orchards, searching for the remnants of Byzantine and Seljukid Melitene. In Eski (or Old) Malatya, the walls of the city, whose construction began under Trajan and was continued by Diocletian and Justinian, can still be visited. Little else remains in Eski Malatya from its Byzantine days, but the Ulu Cami (Great Mosque), constructed by the Seljuks, stands much in the same way as it did in Bar Hebraeus' time. A little way away from Eski Malatya, after a bit of circling in and out of the apricot orchards near the Hittite ruins of Arslantepe, we 
found the remains of a church, which we deduced to have been Armenian.

We asked the local farmer about what the church was, and he was hesitant to share much. Then, when Said our driver spoke to him in Turkish, and obfuscated the fact that we were a group of Christians, the farmer proceeded to share with pride how his forefathers had driven the "infidels," i.e. the Armenians, from the area. The joy with which he recounted the atrocities committed against the Christians was chilling and harsh reminder of the sufferings that the former Christian inhabitants had experienced.

As we left the area of Elazığ and drove back to Diyarbakır, my heart was heavy to leave this place that I had longed to visit my whole life. We stopped in Diyarbakir before going back to Istanbul, and we climbed on top of its basalt walls, walking around the city and looking one last time towards the Tigris flowing away. The senior citizens of Diyarbakir congregate under its walls.

Each memory from this trip is impressed indelibly on my mind. More than the beauty of the surroundings and the architecture, I will remember the faces that we met. Thank you to our wonderful group!! May this be the first of many such trips! May we honor through our scholarship the living heirs and transmitters of the Suryoyo culture and history! ${ }^{4}$

${ }^{4}$ Photographs of the trip can be found on the online version of this paper at http://www.bethmardutho.org/hugoye. These were graciously provided by Hidemi Takahashi, Gareth Hughes, and Alaria Saar. 


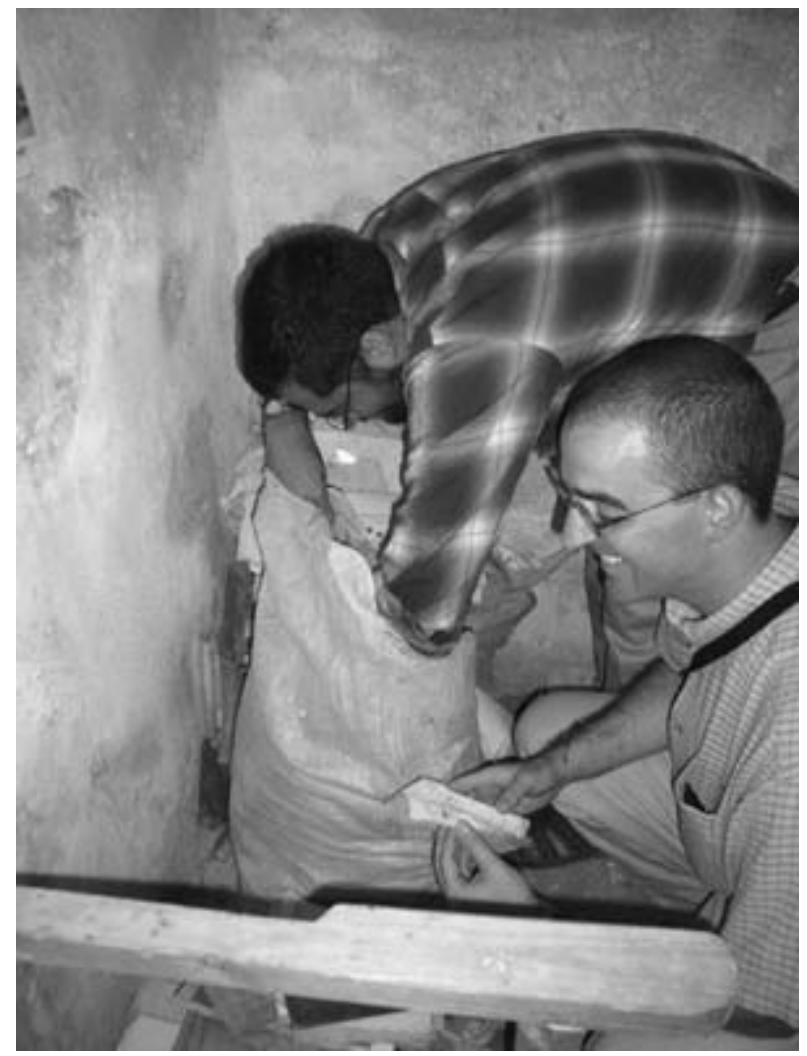

Scavenging for manuscripts at the Church of Mor Yuhannon at Qelleth 